\title{
PEDAGOGICAL KNOWLEDGE OF TEACHING FIGHTS BY TRAINERS IN AN INFORMAL ENVIRONMENT
}

original paper

( ) University School of Physical Education in Wroclaw

DOI: https://doi.org/10.5114/hm.2018.77319

\section{JEFFERSON CAMPOS LOPES ${ }^{1,2}$, EDSON GODOY PALOMARES ${ }^{3}$, BARBARA AGOSTINI PALOMARES ${ }^{3}$, AGATA MARQUES ARANHA ${ }^{2}$, FABIEN PEREIRA SILVA ${ }^{2,4}$}

${ }^{1}$ Faculty of Science and Technology, São Vicente, Brazil

${ }^{2}$ University of Trás-os-Montes and Alto Douro, Vila Real, Portugal

${ }^{3}$ Integrated Faculty of Grande Fortaleza, Fortaleza, Brazil

${ }^{4}$ Estácio de Sá University, Rio de Janeiro, Brazil

\section{ABSTRACT}

Purpose. The aim of the study was to present an investigation into the educational components of teaching fights with the methodologies used in the process of teaching and learning within formal and informal contexts.

Methods. The study is characterized as qualitative, descriptive, and exploratory and was carried out among 8 trainers of each mode (karate, judo, taekwondo, jiu-jitsu, capoeira, muay thai, wrestling, and boxing). An in-depth interview based on a semistructured, adapted questionnaire was applied.

Results. The analysis revealed that the sources of knowledge were numerous and varied, with academic and professional experience as the main sources of professional knowledge. The views of the trainers differed in the ways of teaching of each mode when it came to progression patterns, sequence, emphasis on the content organization, design mode of teaching skills, and level of scope.

Conclusions. Teachers always learn from their students and build their knowledge together. However, fighting is still taught predominantly by giving preferences to mechanical learning of technical gestures. It is necessary to teach content by elaborating new approaches from practical experiences. Further research is needed in the field of sports pedagogy with would focus on the corporal practices, and historical and sociological significance of fighting.

Key words: sports, education, methodology for fights, didactics for fights, fight trainers, teaching and learning

\section{Introduction}

Fighting is a universal human act and is also used by other primates and almost all species. Our ancestors were forced to fight, initially against the hostility of the environment, then to hunt and to conquer women (mating), as well as for political and territorial reasons and disputes [1]. In this study, the term 'fight' was adopted as a unifying word, as it will be discussed in formal and informal environments applying martial or sporting arts of combat.

The term 'fight' has diverse representations and meanings, which give it a 'polysemic' dimension. In re- lation to the context of physical battles, the term 'fight' is circumscribed by intentions of subjugation between subjects of interpersonal conflicts and, sometimes, by contradictory and ambivalent human content [2]. National curriculum parameters (NCPs), however, bring to physical education the definition of fights as disputes in which the opponent must be subjugated through strategies of imbalance, bruises, immobilizations, or exclusion of a particular space in the combination of attack and defence actions. They are characterized by specific regulations aiming to punish acts of violence and disloyalty. Examples of fighting can be cited from tug-of-war games and arm wrestling to more complex

Correspondence address: Fabien Pereira Silva, Universidade Estácio de Sá, Rua do Bispo nº 83, Rio Cumprido Rio de Janeiro, RJ Zip Code 20261-063, Brazil, e-mail: fabien.silva@gmail.com

Received: April 30, 2018

Accepted for publication: July 11, 2018

Citation: Lopes JC, Palomares EG, Palomares BA, Aranha AM, Silva FP. Pedagogical knowledge of teaching fights by trainers in an informal environment. Hum Mov. 2018;19(4):11-19; doi: https://doi.org/10.5114/hm.2018.77319. 
J.C. Lopes, E.G. Palomares, B.A. Palomares, A.M. Aranha, F.P. Silva, Pedagogical knowledge of teaching fight

practices, such as capoeira, judo, and karate [3]. The aims of NCPs involve understanding that schools are places for the teaching of sporting or playful practices in accordance with the law of guidelines and bases of national education. Fights are taught in free education establishments, that is, not as part of the education system; therefore, they are not subordinate to educational law [3, 4].

When talking about pedagogical knowledge, we are trying to identify the knowledge of the technician/ teacher that leads them to define content as a selection of cultural forms or knowledge, concepts, explanations, reasoning, abilities, language, values, beliefs, attitudes, interests, and models of conduct, whose assimilation is considered essential for the adequate development and socialization of the student. It is important to emphasize that not all cultural knowledge and forms are likely to appear as curricular contents, which requires rigorous school selection [5, 6]. In this way, when we refer to content, we encompass concepts, ideas, facts, processes, principles, scientific laws, rules, cognitive skills, modes of activity, methods of understanding and application, study habits, work, leisure and social coexistence, values, convictions, and attitudes.

Thus, 3 aspects of the NCP proposal in the physical education area represent relevant points to be sought within a project to improve the quality of classes: the principle of inclusion; content dimensions (attitudinal, conceptual, and procedural); and cross-cutting themes. In this sense, the proposal highlights school physical education that is addressed to all students without discrimination [3]. It also stresses the importance of articulating the difference between learning to do namely, what is being done and how to relate to it - and explaining the dimensions of the content, and suggests a relationship between the activities of physical education and the major problems of the Brazilian society without losing sight of its role in integrating citizenship in the sphere of corporeal culture. Undoubtedly, these aspects constitute enormous challenges for professionals in the field [3].

This perspective points to the fact that teaching students how to fight involves much mysticism and many practices based on experiences of a primarily practical and intuitive nature, emphasized in the figure of the master as the party primarily responsible for the training of the apprentice. The latter, in turn, learns mainly by performing the asserted procedures, without necessarily questioning or reflecting on them [7]. Therefore, the trainer can be called sensei (karate, judo, jiu-jitsu), but this does not mean 'master.'

Etymologically, decomposing the word 'sensei' re- veals the following: 'sen' means 'ancient, who anticipated,' while 'I know' is imbued with the concept of 'existence, purity.' Therefore, 'sensei' is one who exists before us in a certain field and holds a pure existence, similar to Sabomnin (taekwondo), Grand Master (muay thai), Foreman (capoeira), and Trainer (boxing).

For the learning and teaching process, the meaning of knowledge is related to understanding, wisdom, erudition, being able to determine the area, and being able to understand and explain [8]. Thus, the knowledge of fighting makes it easier to understand the dimensions of knowing how to fight, which makes it easier to know how to teach. The studies by Terrisse [9-11], as well as Sauvegrain and Terrisse [12] initially bring knowledge of practice, which refers to knowledge, regulations, social rules, and values intrinsic to a particular body of practice.

Currently, different approaches to initiating fights are considered. On the basis of the critique of vertical models, which are linked to the predominance of codified technical execution, other models of comprehensive character have emerged that advocate a horizontal and integrated approach to the different competencies of fighting and their technical and tactical constituents. Indeed, there are already 'numerous authors who, starting from a generic and multidisciplinary initiation, have postulated in favour of a multi-purpose initiation in which all the skills proper to the activities of the fight are acquired and perfected,' [13, p. 301]. In the fights related to the life history of teachers, as they may already have experienced a certain activity as practitioners, athletes, trainers, their professional practice is essentially linked to their choices and their analysis is justified in the field of clinical didactics [11].

It is in this line that the concept of 'knowing how to fight' arises. This particular knowledge, inherent in combat dialectics regardless of its dimension and valence, is represented in the fight through the manifestation of a 'tactical intention,' which invokes 'the need to reduce uncertainty in order to facilitate learning and, at the same time, preserve the phases of confrontation without losing the sense of activity,' [14, p. 26-27]. In addition to the approach assumed by these authors, we believe that this concept can also be understood as 'that capacity that allows the sportsman to solve the various situations that occur during a combat, regardless of the technical execution models that characterize the different modalities and whose institutional recognition imposes certain restrictions' [15, p. 46].

'Knowing how to fight' integrates wide technical and tactical practical knowledge, which should emphasize 
the stimulation and manifestation of a 'tactical thought,' whose intentionality reveals a high quality of 'knowing how to fight.' The didactic approach, from this perspective, should imply the recognition and balanced application of the technical and tactical components characterizing the dynamics of fighting in the organization and development of the respective teachinglearning process [16]. Opposition management, the openness of tasks, distance, and purposeful contact, as well as the permanent need to develop meaningful learning should equip the practitioner of a technical performance with consistency and intentionality. There are 3 basic nuclei to which didactic works refer: the didactic transposition, the didactic contract, and the relation with knowledge. The didactic transposition is the passage from a saviour savant to one possessing a learned knowledge (savoir enseigné), and the transfer of this knowledge from the teachers to the students [17]. The didactic contract is a relationship that explicitly and/or implicitly determines the responsibilities of the teacher and student to enable students to obtain knowledge. The relation with knowledge (rapport au savoir) is defined as the way that a subject is affected by knowledge transmitted to him, and the degree to which it is appropriate and related to him $[18,19]$.

In this sense, the aim of the study was to present an investigation into the educational components of teaching fights with the methodologies to be used in the process of teaching and learning within formal and informal contexts.

\section{Material and methods}

The present study assumes a qualitative approach that favours an understanding of the meanings of the participants' experience in a specific environment, as well as the way in which they are configured in certain situations. Therefore, particular methods of observation of the studied context, a detailed recording of the facts, interviews with those involved, and interpretation and analysis of data, described as follows, were used [20].

\section{Participants}

The subjects were selected through the process of intentional sampling of 8 specialists in each mode of fighting, males aged 35-59 years. The criteria for the selection of the interviewees were as follows: minimum graduation to black belt $2^{\text {nd }}$ dan, 5 years of activity, and registration in the respective federation of martial arts.

\section{Observations}

For the present study, observations were made in a non-formal context of teaching fights. We observed 2 classes of each of the modalities investigated. In total, 16 classes were observed, each lasting approximately 2 hours. The total observation time was 32 hours. The observations, divided in terms of modalities, had qualitative research parameters as criteria and involved observing the participants until the procedures began without being repeated [21].

\section{Interviews}

After the observations, interviews were conducted with each of the instructors [22]. The aim of the interviews was to get to know more about the participants, their opinions, teaching methods, knowledge of the modalities, biographical perspectives, teaching and learning processes, and pedagogical practices. We also sought to disregard the relationship of the instructor with his modality, analysing such aspects as the factors that led him to follow this career in addition to the time of practice of his modality, time of action as an instructor, and others.

\section{Data analysis}

The analysis of all the data was performed with the SPSS Software (SPSS Science, Chicago, USA), version 21.

The collected data were submitted to content analysis, which is a methodological instrument with diverse application potential that helps understand structures and models submerged in the fragments of messages [23]. A physical education trainer was also sought to validate the questionnaire.

\section{Ethical approval}

The research related to human use has been complied with all the relevant national regulations and institutional policies, especially the requirements of the National Health Council (Resolution 466/12), has followed the tenets of the Declaration of Helsinki, and has been approved by the authors' institutional review board or an equivalent committee.

\section{Informed consent}

Informed consent has been obtained from all individuals included in this study. 


\section{HUMAN MOVEMENT}

J.C. Lopes, E.G. Palomares, B.A. Palomares, A.M. Aranha, F.P. Silva, Pedagogical knowledge of teaching fight

\section{Results and discussion}

Tables 1-3 help data visualization, comparison, and discussion. The results are presented as per particular questions.

Question 1. What are the sources of knowledge you have? What importance is given to them?
A) Life experience - $50 \%$ (4)
B) Courses - $25.0 \%$ (2)
C) Reading books - $12.5 \%$ (1)
D) Training in physical education $-12.5 \%$ (1)

In this category, we can observe that $50 \%$ of the trainers reported life experience as a source of knowledge, based on their personal life history and daily practice [24-26]. The knowledge of experience was therefore built because a relationship of extreme interiority with its practice was established, making it feel not only similar to a technique, performer, and transmitter of knowledge, but also a legitimate producer of additional valid knowledge, which underlies competence, although this factor remains at the level of noncon- sciousness. Thus, one's life experience is accumulated through years of training, competitions, and other forms of learning. The other $50 \%$ referred to formal education, where knowledge is transmitted through information from the society with multiple educational opportunities.

Question 2. What are the knowledge and skills that the teacher/technician should have in order to facilitate learning?
A) Liabilities - 12.5\% (1)
B) Theory and practice $-37.5 \%$ (3)
C) Know how to teach $-12.5 \%$ (1)
D) Pedagogy - $12.5 \%$ (1)
E) Scientific knowledge $-12.5 \%$ (1)
F) Patience and pleasure $-12.5 \%$ (1)

In this category, we can see that much of the knowledge is rooted in theory and practice where the competence of the teacher is 'essentially didactic,' as well as an optical practicality followed by exercises. This competence stresses the following: 'It helps you to base yourself on the prior representations of the students, without closing them, to find a little input into your

Table 1. Data related to the 8 trainers (age, practice time, activity time)

\begin{tabular}{|c|c|c|c|c|c|c|c|}
\hline \multicolumn{3}{|l|}{ Variables } & \multicolumn{2}{|l|}{ Average } & Maximum & \multicolumn{2}{|c|}{ Minimum } \\
\hline \multicolumn{3}{|l|}{ Age } & \multicolumn{2}{|l|}{44} & 59 & \multicolumn{2}{|c|}{35} \\
\hline \multicolumn{3}{|c|}{ Practice time } & \multicolumn{2}{|l|}{27} & 45 & \multicolumn{2}{|c|}{10} \\
\hline \multicolumn{2}{|c|}{ Time of activity as trainer } & & 21.12 & & 37 & \multicolumn{2}{|c|}{10} \\
\hline Karate & Judo & Taekwondo & Capoeira & Muay thai & Boxing & Jiu-jitsu & Wrestling \\
\hline 59 & 48 & 35 & 48 & 38 & 39 & 45 & 40 \\
\hline 45 & 40 & 17 & 30 & 22 & 23 & 29 & 10 \\
\hline 37 & 28 & 11 & 26 & 07 & 15 & 25 & 10 \\
\hline
\end{tabular}

Table 2. Modality, latest training course, and the time of the course

\begin{tabular}{llc}
\hline Modality & \multicolumn{1}{c}{ Latest training course } & Time of the course (h) \\
\hline Karate & Rolfing structure & 300 \\
& Postgraduate - structural formation & 200 \\
Judo & Fascial fitness (Germany) & 200 \\
Capoeira & None & \\
Muay thai & None & 60 \\
& Arbitration course & 200 \\
Boxing & Course about muay thai (Thailand) & \\
Taekwondo & None & 60 \\
& International course & 1600 \\
Jiu-jitsu & Trainer's course - Olympic Committee of Brazil & 200 \\
Wrestling & Trainer assistants & \\
\hline
\end{tabular}


Table 3. Graduations in the modality, school formation, title as athlete, and title as trainer

\begin{tabular}{|c|c|c|c|c|}
\hline & Graduation & School education & Title: athlete & Title: trainer \\
\hline Karate & $6^{\text {th }}$ dan & $\begin{array}{c}\text { Physical education, government } \\
\text { university }\end{array}$ & $\begin{array}{c}4^{\text {th }} \text { place world championship } \\
1^{\text {st }} \text { place Pan-American } \\
\text { championship }\end{array}$ & $\begin{array}{c}\text { World champion } \\
\text { Pan-American champion } \\
\text { South American champion }\end{array}$ \\
\hline Judo & $6^{\text {th }}$ dan & College, government education & Olympic champion & $3^{\text {rd }}$ Olympic place \\
\hline Capoeira & Master & $\begin{array}{l}\text { Physical education, } \\
\text { private university }\end{array}$ & $\begin{array}{l}\text { Brazilian champion } \\
\text { State champion }\end{array}$ & \\
\hline Muay thai & Black belt & $\begin{array}{l}\text { College, } \\
\text { private education }\end{array}$ & $\begin{array}{l}\text { Continental champion } \\
\text { Pan-American champion }\end{array}$ & $\begin{array}{l}\text { Continental champion } \\
\text { Pan-American champion } \\
\text { Brazilian champion }\end{array}$ \\
\hline Boxing & Teacher & $\begin{array}{l}\text { College, } \\
\text { government education }\end{array}$ & $\begin{array}{c}\text { Open of Cuba } \\
2^{\text {nd }} \text { place Pan-American } \\
\text { Brazilian champion }\end{array}$ & State champion \\
\hline Taekwondo & $5^{\text {th }}$ dan & $\begin{array}{l}\text { Physical education, private } \\
\text { university }\end{array}$ & $\begin{array}{l}\text { Brazilian champion } \\
\text { University champion } \\
\text { Regional champion }\end{array}$ & $\begin{array}{c}3 \text { times Brazilian champion } \\
5 \text { times Brazilian cup } \\
3^{\text {rd }} \text { place Pan-American }\end{array}$ \\
\hline Jiu-jitsu & $5^{\text {th }}$ dan & Architecture, private university & $\begin{array}{l}4 \text { times world champion } \\
4 \text { times Brazilian champion } \\
4 \text { times European champion }\end{array}$ & $\begin{array}{c}\text { World champion } \\
\text { Pan-American champion } \\
\text { European champion }\end{array}$ \\
\hline Wrestling & Teacher & $\begin{array}{c}\text { Physical education, private } \\
\text { university }\end{array}$ & $2^{\text {nd }}$ place state & $\begin{array}{l}2^{\text {nd }} \text { place Brazilian } \\
\text { State champion }\end{array}$ \\
\hline
\end{tabular}

cognitive system, a way of destabilizing them just enough to get them to re-establish the incorporation of new elements into existing representations, reorganizing them if necessary' [26, p. 29]. According to Perrenoud [27], there is a division between passion for art that is done with patience and pleasure, and responsibilities and knowledge built for knowledge about teaching, which is what teachers should know how to do, understand, or profess in order to convert teaching into something more than a form of individual work and to be considered among the prestigious professions [28].

Question 3. What forms should this technique take (base/medium/advanced)?

In this category (Figure 1), fights are revealed to be mutants and changes are necessary, respecting, however, the whole history of the modality, both the positives and the negatives, since most problems arise with errors and thus become sources for new research [29]. We can see that if everyone accepts that learning is done through the fundamentals, then the fundamentals are important for bodily movements that give continuity of knowledge. Already in the intermediate phase, it can be observed that it is essential to focus on the movement itself because movement is conceptually defined as a vision of the result or the production of effective movements in the fulfilment of certain tasks. Movement, therefore, is the instance where the "primordial unity of man and world manifests itself' [29,

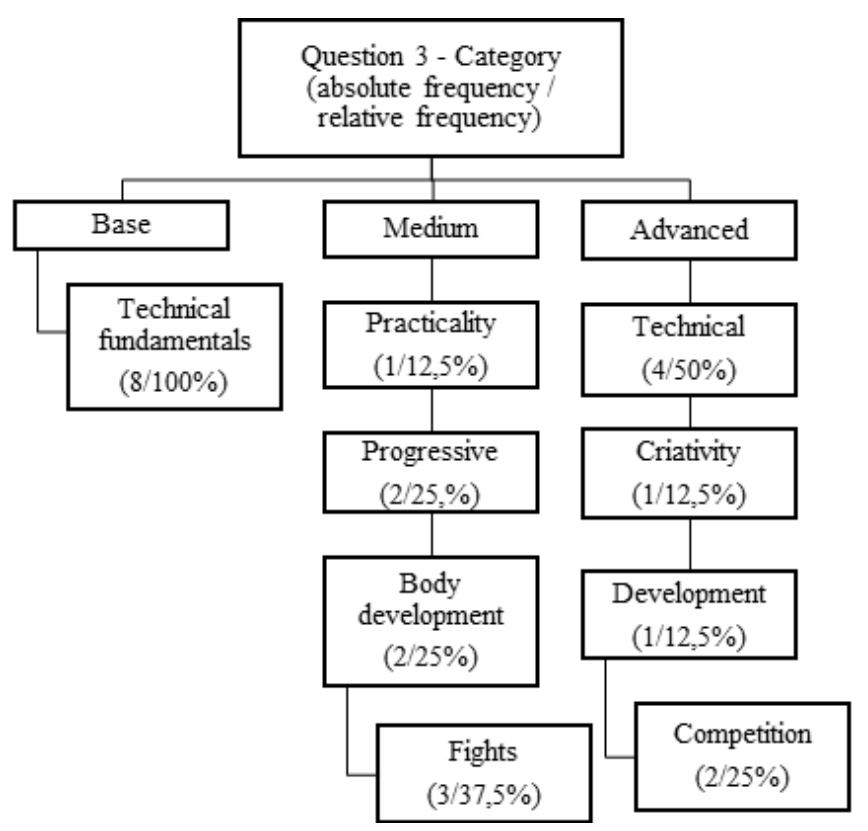

Figure 1. Structure of responses to question 3 


\section{HUMAN MOVEMENT}

J.C. Lopes, E.G. Palomares, B.A. Palomares, A.M. Aranha, F.P. Silva, Pedagogical knowledge of teaching fight

p. 60]. According to Kunz [30], in the advanced practitioner we can see the improvement of techniques as being the primary factor of achievement in the sport, which suggests a pedagogical practice that prioritizes procedures in which the central concern is directed towards whoever makes the gesture, stimulating them to identify and solve problems and still provide the creation of new gestures [31].

Question 4. What are the preferred age groups in your opinion for teaching fighting?
A) All age groups - 50\% (4)
B) Juvenile - 25\% (2)
C) From the age of $10-12.5 \%$ (1)
D) Between 4 and 8 years - $12.5 \%$ (1)

In this category, it will be necessary to acknowledge that academies should divide classes by age group but that owing to the cost of space and hiring professional teachers, the great majority try to include all age groups together. It is evident that students up to 10 years of age should be taught in a playful way, with all possible care in the act of fighting. In addition, there is growth and development, where growth refers essentially to quantitative transformations, while development encompasses both quantitative and qualitative transformations and is a result of aspects associated with the growth process itself, such as physical, biological maturation and experiences in the considered attributes: motor, emotional, social, cognitive performance, etc. Therefore, the professional either applies the same teaching method to all in their classes, with all limitations, or has some help to divide learning by group [32].

Question 5. What are the greatest difficulties that you encounter in teaching fighting?
A) Problems in teaching $-12.5 \%$ (1)
B) Space $-12.5 \%$ (1)
C) Material - $12.5 \%$ (1)
D) Motivation - $12.5 \%$ (1)
E) Lack of commitment - 37.5\% (3)
F) Limitations of the student - $12.5 \%$ -

In this category, the greatest difficulty of teaching fighting turns out to be the lack of commitment because the world today offers numerous technological, social, and behavioural distractions. There is a lack of motivation for regular practice. We can also observe other difficulties, due to the place of teaching not having enough space or material adequate to the specificity of each fight. With respect to limitations, they always stem from lack of specific motor skills that have not been worked on [33].

Question 6. What are the materials and their usage for teaching fighting?

A) Kimono, braid, and floor - 25\% (2)

B) Kimono, floor, gloves, specific gloves - $12.5 \%$ (1)

C) White sack, T-shirt, and musical instruments $12.5 \%(1)$

D) Floor, meshes, and specific equipment - 12.5\% (1)

E) Trousers, shirts, bags, mitts, mouthwash, and bandages - $25 \%$ (2)

F) Dobo, head and chest protector, rackets - 12.5\% (1)

In this category, we can present the types of fighting being practised by their different characteristics. The types of fighting bring to the world of physical education elements of tradition, religion, culture, philosophy, rituals, and discipline, as well as aspects related to colour, which can be transmitted, preserved, and reorganized to the needs of a particular context. Thus, each mode carries with it its history, its origin, its dress, its traditions, and its characteristics that correspond with each manifestation of fight [34].

Question 7. What do you understand by methodological didactic procedures of content? What would be a correct pedagogical sequence of a student's learning?

In this category (Figure 2), there was a split within the question, resulting in $50 \%$ focus on teaching,

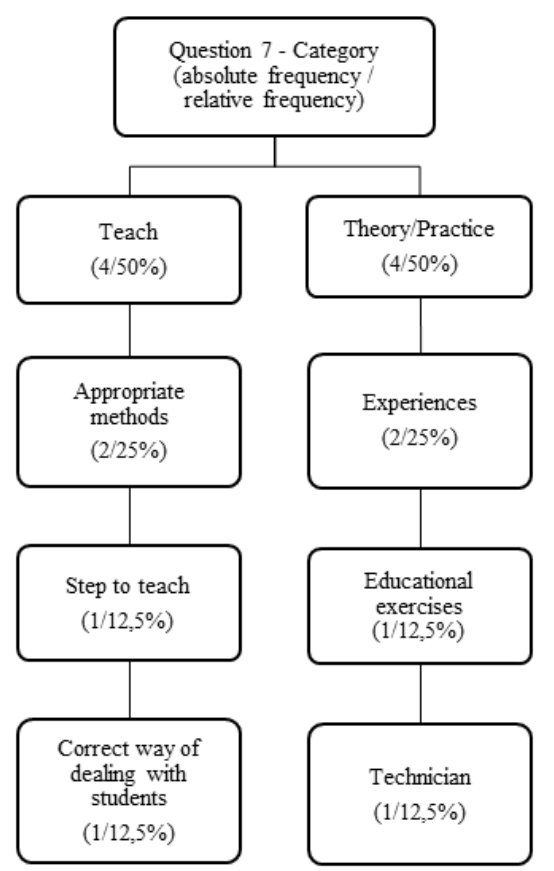

Figure 2. Structure of responses to question 7 
for the most part. Emphasis is also put to methods and ways to teach. Therefore, we need to better understand that teaching involves, as a reference, what can be transmitted as learning components that stimulate the student [35]. Thus, the didactic procedure that is most adequate for the learning of certain content is one that helps the student to incorporate new knowledge in an active, comprehensive, and constructive way. In the case of fighting, the literature has pointed out some theoretical and methodological approaches which seek other ways of understanding, not limited to teaching only some experiences of one or a few specific modalities [7, 36, 37]. Here, we can see that the pedagogical sequence goes directly from theory and practice to $50 \%$, with experiences, educational exercises, and fundamentals for teaching fighting.

Question 8. How should the process of teaching fighting be organized for the progression of a competitive athlete?
A) Increase in the problem - $12.5 \%$ (1)
B) Phases and competitions - $12.5 \%$ (1)
C) Competition levels - 37.5\% (3)
D) Training worksheet $-12.5 \%$ (1)
E) Periodization - 25\% (2)

In this category, we emphasize the athlete who always ends up being promoted in the academy, where the strong linking of sports with the need to achieve high-efficiency yields has focused on the training processes and strategic planning related to competitions. Thus, educational issues are left in the background. In this sense, competition is a way of clear progression within the organization of training [38].

Question 9. Do you work on fundamental motor skills with students up to the age of 10 ? If not, why? If so, which skills do you work on?

In this category, most trainers reported working on the fundamental motor skills that involved components of stability, locomotion, and manipulation, as the refinement and development of these standards help the child reach a complex level of movement. The fundamental motor skills are considered to be common movements, with a general goal to serve as the basis for more complex movements; that is, they act as building blocks for learning more complex abilities, whether in sports or not [39].
Question 10. What, in your opinion, is your contribution to your increasingly evolving mode?

A) Improving training - $37.5 \%$ (3)

B) Evolution besides sport - 12.5\% (1)

C) More exchange - $12.5 \%$ (1)

D) Improve working conditions - $12.5 \%$ (1)

E) Satisfaction and competence $-12.5 \%$ (1)

F) Ethics factors - 12.5\% (1)

In this category, it can be noted that the evolution of fighting requires improvement in the formation. As with any area of activity, professional knowledge represents the set of knowledge that empowers the individual to exercise their profession, which makes them able to perform all their functions. This knowledge builds on initial and continuing training and is enhanced by the daily practice of the profession. The construction takes place both in the individual and in the collective field, as people learn much from one another and from themselves. In addition, it is essential that there be a set of reflections on possible paths.

\section{Conclusions}

In the present study, we analysed the teaching and learning processes of some instructors of different fighting modalities - karate, judo, taekwondo, jiu-jitsu, capoeira, muay thai, wrestling, and boxing - in the nonformal contexts of teaching (gyms, clubs, and sports centres). The teaching of fighting in non-formal contexts is an attempt to develop pedagogical practices in these environments, which, as analysed throughout the work, are filled with predominantly traditionalist doctrines and beliefs. In this way, pedagogy in these areas refers to the methodological, procedural, and planning-related processes of educational practice, but it is also linked to the values, concepts, and behaviours.

As noted in the contexts analysed, fighting is still taught predominantly by giving preferences to mechanical learning of technical gestures. This fact demonstrates the lack of relation between critical and innovative pedagogical aspects and the teaching of fighting. This suggests the need for further studies in the field of sports pedagogy with a focus on the corporal practices, and historical and sociological importance of fighting.

Teachers agree that, regardless of their background, they always learn from their students and build their knowledge together; that is, the formation of a teacher never ends because the professional is always in the process of learning. Whether they are in a school setting, academia, or an academy, they have to train people, 
J.C. Lopes, E.G. Palomares, B.A. Palomares, A.M. Aranha, F.P. Silva, Pedagogical knowledge of teaching fight

and perhaps future teachers, who can think through practices and demystify the common sense that fighting conveys.

However, it is necessary for a fighting specialist to teach content by elaborating new approaches from practical experiences, which will certainly lead to new questions, taking each reality into account. These new questions or problems should not be perceived as obstacles but rather as starting points for restructuring the daily pedagogical work since this is a normal condition for those who adopt a posture of constant learning and who understand the eternal alteration of knowledge; being of an admittedly provisional character, knowledge is always capable of being signified again according to specific historical realities, conceptions, and moments.

\section{Disclosure statement}

No author has any financial interest or received any financial benefit from this research.

\section{Conflict of interest}

The authors state no conflict of interest.

\section{References}

1. Paiva L. A clinical look at fights, martial arts, and combat modalities [in Portuguese], $1^{\text {st }}$ ed. Manaus: OMP Editora; 2015.

2. Correia WR, Franchini E. Academic papers about fight, martial arts and combat sports [in Portuguese]. Motriz Rio Claro. 2010;16(1):1-9; doi: 10.5016/1980-6574. 2010v16n1p01.

3. Brazilian Ministry of Education and Sport. National curriculum parameters: physical education [in Portuguese]. Brasília, 1997.

4. Boudens E. Fights and martial arts study as legislative advice [in Portuguese]. Brasília: Camara dos Deputados; 2002.

5. Coll C, Juan IP, Sarabia B, Vallis E. Content in the reform: teaching and learning concepts, procedures, and attitudes [in Portuguese]. Porto Alegre: Artes Médicas; 2000.

6. Libâneo JC. Didactics [in Portuguese]. São Paulo: Cortez; 1994.

7. Breda M, Galatti L, Scaglia AJ, Paes RR. Pedagogy of sports applied to fights [in Portuguese]. São Paulo: Phorte; 2010.

8. Ferreira ABH. New dictionary of the Portuguese language [in Portuguese], $3^{\text {rd }}$ ed. Curitiba: Positivo; 2004.

9. Terrisse A. The question of knowledge in the didactics of the APS: test of formalization. Ability to conduct researches [in French]. Toulouse: Université Paul Sabatier; 1994.

10. Terrisse A. Epistemology of clinical research in combat sports [in French]. In: Terrisse A (ed.), Martial arts and martial arts research, state of the art, research, and training collection [in French]. Paris: Revue EPS; 2000; 95-108.

11. Terrisse A. Clinical didactics in EPS. Origin, theoretical framework, and empirical research [in French]. In: Terrisse A, Carnus MF (eds.), Clinical didactics of physical education and sports: challenges of knowledge [in French]. Bruxelles: De Boeck Université; 2009; 13-33.

12. Sauvegrain JP, Terrisse A. Identification of the difficulties of appropriation of the knowledge to fight by a methodology of didactic engineering [in French]. Rev Sci Motr. 1998;32-33:74-87.

13. Espartero J, Gutiérrez C, Villamóm M. The fighting activities [in Spanish]. In: Tabernero B, Vázquez S (eds.), Physical education: proposals for change [in Spanish]. Barcelona: Editorial Paidotribo; 2003; 283-324.

14. Terrissee A. Analysis of didactic transposition in judo: evolution of the fight knowledge in teaching judo at school through PE in years 1950-1993 [in French]. Revue Française de Pédagogie. 1996;116:65-75.

15. Avelar B, Figueiredo A. Introduction to combat sports: explanation of the structure of the human combative phenomenon [in Spanish]. Rev Artes Marciales Asiat. 2009;4(3):44-57.

16. López Ros V, Castejón Oliva FJ. The integrated technical-tactical education of school-age sports. Explanation and bases of a model [in Spanish]. Apunts Educ Fisica Deport. 2005;79(1):40-48.

17. Chevallard Y. The didactic transposition [in French]. Grenoble: La Pensée Sauvage; 1985.

18. Brousseau G. Foundations and methods of didactics [in French]. In: Balacheff B, Cooper M, Sutherland R, Warfield V (eds.), Theorization of didactic situations [in French]. Grenoble: La Pensée Sauvage; 1998; 47-109.

19. Jourdan I. Study of the relation with knowledge among students in initial EPS training [in French]. In: Terrisse A, Carnus MF (eds.), Clinical didactics of physical education and sports: challenges of knowledge [in French]. Bruxelles: De Boeck Université; 2009.

20. Creswell JW. Research project: qualitative, quantitative, and mixed methods [in Portuguese], $2^{\text {nd }}$ ed. Porto Alegre: Artemed; 2007.

21. Thomas JR, Nelson JK, Silverman SJ. Research methods in physical activity. Champaign: Human Kinetics; 2011.

22. Triviños ANS. Introduction to research in social sciences: qualitative research in education [in Portuguese]. São Paulo: Atlas; 1987.

23. Bardin L. Content analysis [in Portuguese]. Lisboa: Edições 70; 2006.

24. Tardif M. Teachers' knowledge and vocational training [in Portuguese], $8^{\text {th }}$ ed. Petrópolis: Vozes; 2007.

25. Pimenta SG. (Org.). Pedagogical knowledge and teaching activity [in Portuguese]. São Paulo: Cortes; 1999.

26. Ferreira Borges CM. The teacher of basic education and their professional knowledge [in Portuguese], $1^{\text {st }} \mathrm{ed}$. Araraquara: JM Editora; 2004. 
27. Perrenoud P. Ten new skills to teach [in Portuguese]. Porto Alegre: Artmed; 2000.

28. Shulman LS. Knowledge and teaching: foundations of the new reform [in Spanish]. Prof Rev Curr Form Prof. 2005;9(2):1-30.

29. Moreira SM. Pedagogy of sport and karate-do: considerations about initiation and early sports specialization [in Portuguese]. Master thesis. Campinas: University of Campinas; 2003.

30. Kunz E. Didactic and pedagogical transformation of sport [in Portuguese]. Ijuí: Unijuí; 1994.

31. Paes R.R. Pedagogy of sport: contexts, evolution, and perspectives [in Portuguese]. Rev Bras Educ Fis Esp. 2006;20(Suppl. 5):171.

32. Roche AF, Sun SS. Human growth: assessment and interpretation. Cambridge: University Press; 2003.

33. Bento J, Garcia R, Graça A. Contexts of sport pedagogy: perspectives and problems [in Portuguese]. Lisboa: Livros Horizonte; 1999.

34. Peas RR. The pedagogy of sport and collective games [in Portuguese]. In: De Rose D Jr (ed.), Sport and physical activity in childhood and adolescence: a multidisciplinary approach [in Portuguese]. Porto Alegre: Artmed; 2002; 89-98.

35. Rufino LGB. Fighting techniques: the process of collective construction of a high school textbook in physical education [in Portuguese]. Master thesis. Rio Claro: São Paulo State University; 2012.

36. Gomes MSP, Morato MP, Duarte E, Almeida JJG. The teaching of fighting techniques: from conditional principles to situational groups [in Portuguese]. Movimento. 2010;16(2):207-227; doi: 10.22456/1982-8918.9743.

37. Gomes MSP. Pedagogical procedures for the teaching of fighting techniques: contexts and possibilities [in Portuguese]. Master thesis. Campinas: University of Campinas; 2008.

38. Bento JO. From pedagogy to sport [in Portuguese]. In: Tani G, Bento JO, Petersen RDS (eds.), Pedagogy of sport [in Portuguese]. Rio de Janeiro: Guanabara Koogan; 2006; 26-40.

39. Goodway JD, Branta CF. Influence of a motor skill intervention on fundamental motor skill development of disadvantaged preschool children. Res Q Exerc Sport. 2003;74(1):36-46; doi: 10.1080/02701367.2003. 10609062 . 